\title{
Combining geomorphological-hydrological analyses and the location of settlement and raw material sites - a case study on understanding prehistoric human settlement activity in the southwestern Ethiopian Highlands
}

\author{
Elena A. Hensel ${ }^{1}$, Oliver Bödeker ${ }^{2}$, Olaf Bubenzer ${ }^{3}$, and Ralf Vogelsang ${ }^{4}$ \\ ${ }^{1}$ Institute of Geography, University of Cologne, Cologne, 50923, Germany \\ ${ }^{2}$ Department of Geoscience, University of Cologne, Cologne, 50923, Germany \\ ${ }^{3}$ Institute of Geography \& Heidelberg Center for the Environment (HCE), Heidelberg University, \\ Heidelberg, 69120, Germany \\ ${ }^{4}$ Institute of Prehistoric Archaeology, University of Cologne, Cologne, 50923, Germany
}

Correspondence: $\quad$ Elena A. Hensel (elena.hensel@ uni-koeln.de)

Relevant dates: $\quad$ Received: 8 January 2019 - Revised: 26 August 2019 - Accepted: 29 August 2019 Published: 17 October 2019

How to cite:

Hensel, E. A., Bödeker, O., Bubenzer, O., and Vogelsang, R.: Combining geomorphologicalhydrological analyses and the location of settlement and raw material sites - a case study on understanding prehistoric human settlement activity in the southwestern Ethiopian Highlands, E\&G Quaternary Sci. J., 68, 201-213, https://doi.org/10.5194/egqsj-68-201-2019, 2019.

Abstract:

During this study, the recent relations between the hydrological systems and the distribution of archaeological sites and obsidian raw material outcrops within the catchment of the Bisare River, around Mt Damota, and around Mt Sodicho in the southwestern Ethiopian Highlands were investigated. To do so, we combined geomorphological-hydrological analyses with field surveys and GIS mapping. The aim was to try to transfer these recent interrelations into the past to better understand the factors that influenced prehistoric human settlement activity. The natural geomorphodynamics in landscapes such as the southwestern Ethiopian Highlands were and still are characterized by the interplay between endogenous processes (tectonics, volcanism) and climatic fluctuations and, during the recent past, also by human activity. In the considered region, protective and potentially habitable rock shelters are found at the volcanic slopes of Mt Damota and Mt Sodicho at high elevations. In addition, in some areas recent morphodynamic processes make obsidian raw material available near the surface. However, archaeological and terrestrial paleoenvironmental archives that allow an understanding of the interplay between prehistoric settlement activity and paleoenvironmental conditions are still rare. Therefore, the surroundings of formerly occupied rock shelters were investigated to illustrate the effect of the recent fluvial morphodynamics (erosion and accumulation) on surface visibility and preservation of archaeological obsidian raw material. This recent information can be used to make assumptions about the former hydrological system and to thereby get answers to research questions such as those about the past accessibility of obsidian raw material for prehistoric humans. The results suggest that the study area is currently affected by a highly dynamic hydrological system, which is indicated by phenomena such as the formation of swamps due to sedimentation in natural depressions. In addition, wide areas 
of the Bisare River catchment are affected by gully erosion, which leads to land degradation but also to the exposure of the above-mentioned lithic raw material outcrops. Human influence strongly increased during the Holocene until today, especially on the mountain flanks. This in turn increased soil loss and erosion of archaeological sites, which complicates the transfer of the current morphodynamics into the past. Although it cannot be finally confirmed that prehistoric hunters and gatherers systematically used fluvially exposed raw material, based on our results it can be assumed that humans frequented this area, due to the local availability of such kind of material.

Kurzfassung:

Im Rahmen dieser Studie wurden die aktuellen Zusammenhänge zwischen hydrologischen Systemen, sowie der Verbreitung archäologischer Fundplätze und von Obsidian-Rohmateriallagerstätten im Einzugsgebiet des Bisareflusses, um Mount Damota sowie um Mount Sodicho im südwestlichen äthiopischen Hochland untersucht. Hierfür wurden geomorphologisch-hydrologische Analysen mit Geländesurveys und Gis-Kartierungen kombiniert. Das Ziel war der Versuch, die aktuelle Situation in die Vergangenheit zu übertragen, um die prähistorische menschliche Siedlungsaktivität besser zu verstehen. Das natürliche geomorphologische Prozessgeschehen in Landschaften wie dem südwestlichen äthiopischen Hochland wurde und wird durch das Zusammenspiel von endogenen Prozessen (Tektonik, Vulkanismus) sowie Klimaschwankungen und in jüngster Zeit auch durch menschliche Aktivitäten geprägt. In der betrachteten Region finden sich höher gelegene, schützende und potentiell bewohnbare Felsüberhänge (Rockshelter) an den Vulkanhängen des Mt. Damota und des Mt. Sodicho. Außerdem wird durch aktuelle morphodynamische Prozesse in einigen Bereichen Obsidian als Rohmaterial oberflächennah verfügbar. Archäologische und terrestrische Paläoumweltarchive, die es ermöglichen, das Zusammenspiel zwischen prähistorischer Besiedlung und Umweltbedingungen zu verdeutlichen, sind jedoch noch selten. Daher wurde die Umgebung der ehemals bewohnten Rockshelter untersucht, um die Auswirkungen der rezenten fluvialen Morphodynamik (Abtragung und Akkumulation) auf die oberflächennahe Sichtbarkeit und Erhaltung archäologischer RohmaterialFundstellen zu verdeutlichen. Die gewonnen Informationen können dafür verwendet werden, Annahmen über das ehemalige hydrologische System zu treffen und somit Antworten auf Forschungsfragen wie jener nach der ehemaligen Zugänglichkeit von Obsidian-Lagerstätten für den prähistorischen Menschen zu erhalten. Die Ergebnisse legen nahe, dass das Untersuchungsgebiet derzeit von einem hochdynamischen hydrologischen System geprägt wird, was sich beispielsweise durch Phänomene wie der Ausbildung von Sümpfen aufgrund von Sedimentation in natürlichen Depressionen zeigt. Darüber hinaus stehen weite Bereiche des Einzugsgebiets des Bisareflusses unter dem Einfluss von Gullyerosion (Grabenerosion), welche zu Bodendegradierung und zur Freilegung der oben genannten lithischen Rohmaterialien führt. Insbesondere an den Bergflanken nahm der anthropogene Einfluss während des Holozäns stark zu. Dies wiederum verstärkte den Bodenabtrag und die Erosion archäologischer Fundstellen, was den Transfer der aktuellen Morphodynamik auf die Vergangenheit erschwert. Obwohl nicht eindeutig nachgewiesen werden kann, dass prähistorische Jäger und Sammler fluvial freigelegtes Rohmaterial gezielt nutzten, kann basierend auf unseren Ergebnissen davon ausgegangen werden, dass die lokale Rohmaterialverfügbarkeit zu einer verstärkten Frequentierung der Region durch prähistorische Menschen führte.

\section{Introduction}

The landscape of the southwestern Ethiopian Highlands was created by tectonic stresses and Late Pleistocene-Holocene eruptive activity, as well as by the increasing influence of human activity in recent times. The development of topographic barriers and natural basins that were induced by tectonic uplift or faulting created a complex relief with ridges and ravines (De La Torre et al., 2007; Benito-Calvo et al., 2007). Large areas of today's surface are influenced by erosional processes, for example, by widespread gully erosion and badlands formation that are common causes of morphological transformations in Ethiopia today (Billi and Dramis, 2003). In many cases, this development is linked to human influence and the intensification of agriculture (Castillo and Gómez, 2016). Up to now, there are only a few terrestrial geoarchives in East Africa with reconstructions of Pleistocene and Holocene precipitation or temperature changes (Tierney et al., 2008; Tierney et al., 2011; Foerster et al., 2012, 2015). Due to the rare paleoclimatic data but also due to the lack of valuable archaeological information, there is 
still an ongoing discussion on how short- and long-term climatic events and trends affected prehistoric humans living on the Horn of Africa. Available paleoclimatic records from lake sediments from Ethiopia and Kenya document wet-dry transitions that likely affected prehistoric humans and their adaption to the changing environment. In this context, one proposed hypothesis is the retreat of human groups into highland regions with higher precipitation rates during dry periods (Basell, 2008; Foerster et al., 2015; Junginger and Trauth, 2013).

Our study discusses the following research questions. (1) How does the actual hydrological system of the study area look like? (2) What role does this system play in present accessibility of obsidian raw material sources and the visibility and preservation of archaeological sites? (3) Which geomorphological features related to erosion are present? (4) Can we make assumptions about the ancient hydrological system and landscape dynamics and, on their influence, on the accessibility of past obsidian raw material sources? For our studies we selected three research areas in the southwestern Ethiopian Highlands, ca. $250 \mathrm{~km}$ southwest of Addis Ababa, that are located within a radius of $40 \mathrm{~km}$ of one another (Fig. 2). (1) Mt Damota is a volcanic mountain that became of archaeological interest because of its key site, the Mochena Borago Rockshelter, which is one of the most important Late Pleistocene and Holocene sites in eastern Africa (Brandt et al., 2012). (2) Mt Sodicho is located ca. $40 \mathrm{~km}$ to the northwest of Mt Damota and marks the second research area. The archaeological site Sodicho Rockshelter is located on the southern flanks of this volcanic mountain. (3) The banks of the Bisare River, a tributary of the Bilate River, are located southeast of Mt Damota (Fig. 2a).

Archaeological records within the rock shelter sediments of, e.g. Mt Damota or Mt Sodicho, provide information about ancient human-environment interactions. Additionally, numerous open-air sites at the slopes of Mt Damota provide a complementary record of former human settlement (Brandt et al., 2012; Vogelsang and Wendt, 2018). The main trench at Mochena Borago yielded three major lithostratigraphic units with archaeological material classified as Middle Stone Age (MSA), dating to ages between 36 and $>50 \mathrm{ka}$ (Brandt et al., 2017). However, a sedimentological hiatus in the stratigraphy from $\sim 36$ to $\sim 8 \mathrm{ka}$ leaves unanswered questions about deposition processes and the occupation at that site until the Holocene (Brandt et al., 2012, 2017). Vogelsang and Wendt (2018) examined multiple archaeological surface localities classified as MSA and Late Stone Age (LSA) sites on the western flank of Mt Damota to reconstruct prehistoric settlement patterns. They recognized intensification of settlement activities from the MSA to the LSA, as well as a different organization of the site clusters along the mountain slopes. Whereas the reconstructed MSA settlement areas show a linear, vertical orientation and include different altitudinal belts, the LSA sites form one large cluster with interconnected smaller sub-groups. The former is interpreted as a land use model that offered short access to various eco-zones in different elevations, a strategy that might have been advantageous during times of environmental stress. Following our first results for the Sodicho Rockshelter, archaeological settlement layers with preserved and recently dated lithic material fill the Late Pleistocene and Holocene occupational gap ( $\sim 36$ to $\sim 8 \mathrm{ka}$ ) from Mochena Borago. Generally, the volcanic rocks of Mt Damota and Mt Sodicho do not contain any naturally occurring obsidian, although this is the most common raw material used for the production of stone artefacts at all archaeological sites in the region (Brandt et al., 2012, 2017). The third study area at the permanent Bisare River site shows a high potential for geoarchaeological investigation (Benito-Calvo et al., 2007), since obsidian raw material was exposed by gully erosion and archaeological artefacts from all stone age periods are scattered within the catchment area. The main causes of gully formation and further development are still not clear, although several factors are potentially relevant for the development of this incision. These often include, e.g. higher precipitation after arid phases, loose topsoil material, and sparse vegetation due to intense land use (Billi and Dramis, 2003; Fryirs and Brierley, 2013; Mukai, 2017). By studying swamp formation in the upper Bisare catchment, the influence of alternating wet and dry phases on the regional landscape dynamics could exemplarily be investigated for the last several years (for long-term climatic fluctuations, please compare Trauth et al., 2019). These alternations lead to changes in erosion and deposition. Generally, our analysis of the landscape archive at the Bisare River sheds light on site preservation and raw material availability.

In order to understand ancient human-environment interactions, understanding the past morphodynamics is crucial. We followed a diachronous approach and tried to transfer today's knowledge about the local fluvial dynamics that affect archaeological assemblages and raw material outcrops by degradation into the past. In the framework of this study we applied geomorphological and hydrological analyses via remote sensing and field surveys. In doing so, we mapped the current flow directions and stream networks and compared these with signs of former human occupation.

\section{General settings of the study area}

\subsection{Geological and geomorphological setting}

The study area is located in the southwestern Ethiopian Highlands north of Lake Abaya, between the north-south-running Omo River in the west and the Bilate River in the east, at the border of the western central and southern Main Ethiopian Rift and the southern Ethiopian Plateau (Fig. 1b). On average, the mountain ranges rise to $2000-3000 \mathrm{~m}$ above sea level (a.s.l.). Plio-Pleistocene volcanic activity and Late Pleistocene to Holocene tectonic stress formed characteristic natural basins, steep slopes, and gorges. Silicic volcanic material, including the trachytic solid rocks of Mt Damota and 


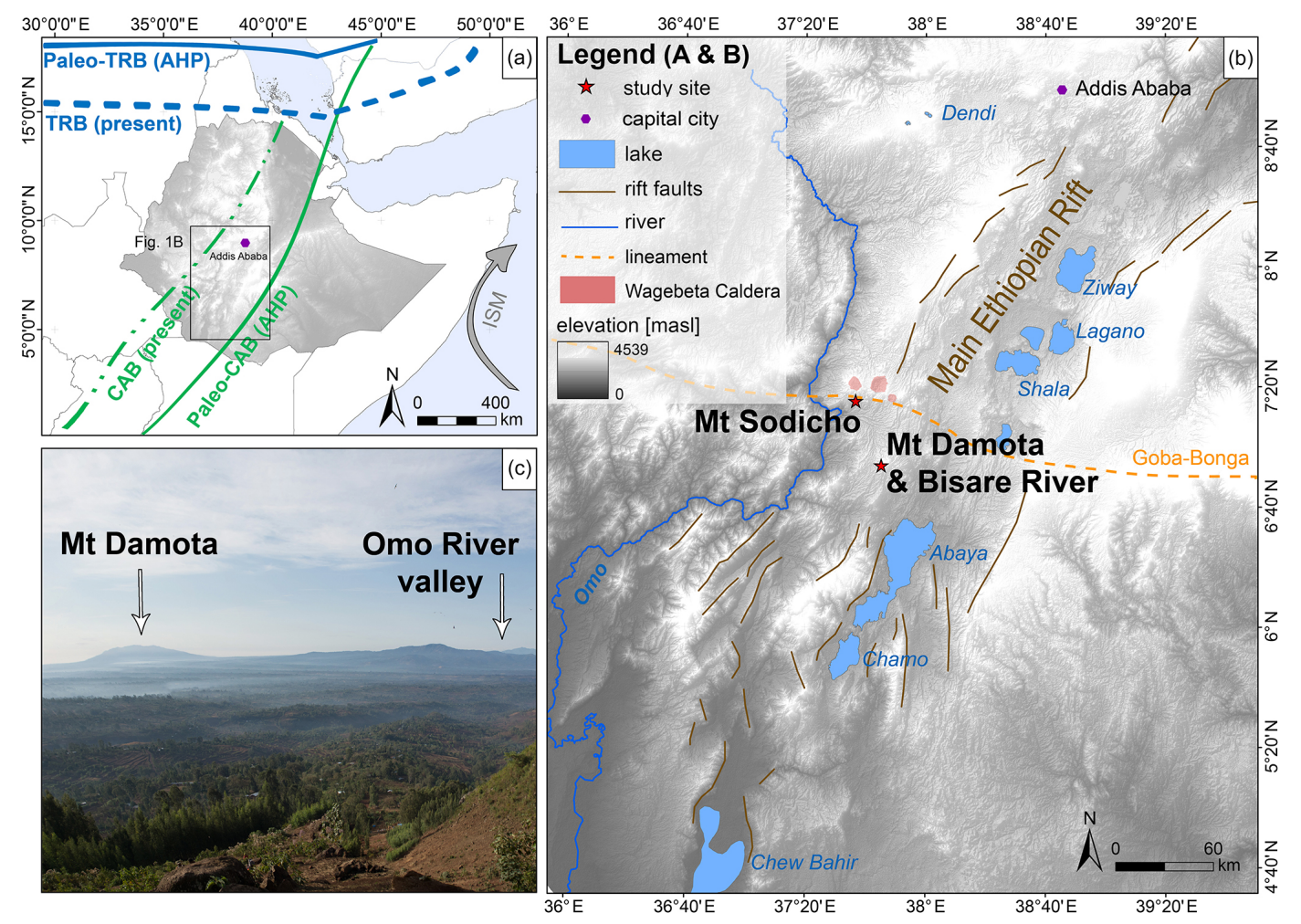

Figure 1. (a) Map showing the flow of the Indian Summer Monsoon (ISM) and the current northernmost position of the tropical rain belt (TRB) during August (TRB, present) and its shifted northernmost position for August during the African humid period (Paleo-TRB, AHP, $\sim 15 \mathrm{ka} \mathrm{BP}$ to $\sim 5 \mathrm{ka} \mathrm{BP}$ ). The map also refers to the present position of the Congo Air Boundary (CAB) and its shift during the AHP (modified from Junginger and Trauth 2013). (b) Research area at the rift margins in the southwestern Ethiopian Highlands, showing the major geological fault system of the Main Ethiopian Rift, the big lake systems, the Wagebeta Caldera Complex, and the Goba-Bonga lineament. The study sites are marked by red stars (DEM data by ASTER GDEM; illustration by Elena Hensel). (c) Photo taken from the southern flank of Mt Sodicho, showing the silhouette of Mt Damota and the Omo River valley (viewing direction south-southwest) (Photo by Christian Schepers, illustration by Elena Hensel).

Mt Sodicho, is part of the rift shoulder trachytic volcanism, which developed in the Pliocene during the late stages of the formation of the Ethiopian Rift (Chernet, 2011; Corti et al., 2013; Abbate et al., 2015).

Mt Damota is a dormant igneous volcanic mountain with a height of $2908 \mathrm{~m}$ a.s.l., which is primarily composed of greenish grey trachyte (Brandt et al., 2012). It is part of a larger silicic complex and overlies a pyroclastic rock formation of rhyolitic to trachytic lava and ignimbrites that are associated with the Nazret Group (Chernet, 2011; Corti et al., 2013). Woldegabriel et al. (1990) assumed a formation of the trachytic flows of the volcano during the Late Pliocene ( $\sim 2.9 \mathrm{Ma})$. Mt Sodicho, with an elevation of about 2100 ma.s.l., belongs to the Wagebeta Caldera Complex (Fig. 1b). The mountain lies directly on the Goba-Bonga lineament, a transversal east-west depression with transversal structures that crosses the Main Ethiopian Rift (Bonini et al., 2005; Corti, 2009; Corti et al., 2013). The Bisare River catchment is situated southwest of Mt Damota within the Hobitcha Caldera structure (Fig. 2c). The river is a western tributary of the Bilate River that flows into the northern part of Lake
Abaya. This lake is located in a quasi-endorheic basin (Schütt et al., 2005). The Bisare River is associated with glacis and valley fills including interbedded volcanic rocks. The latter are not older than $200 \mathrm{ka}$ and developed from the Middle to Upper Pleistocene up to the Holocene (De La Torre et al., 2007). Archaeological finds in the area of the Bisare River catchment comprise open-air artefact scatters and widespread raw material locations, which are currently exposed as a result of river incision (Benito-Calvo et al., 2007; De La Torre et al., 2007; Abbate et al., 2015; Vogelsang, unpublished observation, 2011, 2012).

\subsection{Climatic setting}

The Ethiopian Highlands receive more than $2000 \mathrm{~mm}$ of annual rainfall, which is the highest average amount at the Horn of Africa (Griffith, 1972; Viste and Sorteberg, 2013). Annual climatic variations in Ethiopia are related to moisture brought by the summer monsoon that interacts with the dry northeastern "Harmattan" wind system and to changes in the north-south directed pressure gradient (Viste and Sorteberg, 
2013; Nicholson, 2018). A further influence is changes in sea surface temperatures of the adjacent Indian Ocean (Griffith, 1972; Tierney et al., 2008; Segele et al., 2009; Viste et al., 2013). Inter-annual changes in precipitation are linked to the shifting of the tropical rain belt (TRB), low-level convergences, and the role of the accentuated topography (Nicholson, 2018) (Fig. 1a). The Congo Air Boundary (CAB) is an additional but less relevant source for moisture variability in Ethiopia (Junginger and Trauth, 2013). Most of the annual precipitation $(50 \%-90 \%)$ falls during boreal summer from June to September, called "Kirmet" in this area. Regions with the highest precipitation receive up to $350 \mathrm{~mm}$ of rainfall per month (Berhanu et al., 2013). The vegetation of the study area around Mt Damota and Mt Sodicho encompasses two classification types according to Friis et al. (2010): grasslands and mountainous woodland between 1600 and $3300 \mathrm{~m}$ a.s.l. belong to the "dry evergreen montane forest and grassland complex" classification and evergreen trees between 1500 and $2600 \mathrm{~m}$ a.s.l. to the "moist evergreen montane forest" classification. The mountain flanks of Mt Damota and Mt Sodicho were reshaped by human deforestation, intensive subsistence farming, and subsequent partly severe soil erosion during the last few decades (Fig. 1c). The paleoclimate of southwestern Ethiopia of the last $45 \mathrm{ka}$ was characterized by fluctuations of moister and drier conditions (Foerster et al., 2012; Trauth et al., 2019). According to the paleoclimate record of the Chew Bahir drill cores, arid conditions during the Last Glacial Maximum (LGM, 24-18 ka) led to a desiccation of the former paleolake (Foerster et al., 2012, 2015; Trauth et al., 2019) (Fig. 1b). Subsequently, an abrupt change is visible after $\sim 15 \mathrm{ka}$ with a transition from extreme arid to humid conditions, marking the starting point of the African humid period (AHP, 15 to $5 \mathrm{ka}$ ). This was a period with a generally higher and stable availability of moisture but was, however, interrupted by several dry spells. Exemplary arid phases were the Older Dryas stadial (OD, $\sim 14 \mathrm{ka}$ ) and the Younger Dryas event (YD, 12.8-11.6 ka), followed by shorter dry events $(\sim 10.5, \sim 9.5,8.15-7.8$ and $\sim 7 \mathrm{ka}$ ). The end of the AHP was marked by an increase in aridity that persists to this day. Exceptions were short humid events at $\sim 3, \sim 2.2$, and 1.3 ka (Foerster et al., 2012, 2015).

\section{Material and methods}

\subsection{Mapping and survey}

The research areas around Mt Damota and Mt Sodicho were mapped during field surveys from 2015 to 2018 that were supported by high-resolution satellite imagery. Geomorphological mapping in the field included the description of rock outcrops, surface exposures, geomorphological features, and signs of the influence of extensive modern human occupation in the area. Afterwards, topographical features such as reliefs and slopes, as well as drainage ways and further geomorphological properties, were extracted from a high-resolution dig- ital elevation model (DEM) (Sect. 3.2). Archaeological surveys in the surrounding area of Mt Damota were conducted from 2010 to 2014, resulting in the discovery of 63 open-air sites. The surveys included different landforms of the tropical highlands in various altitudes, following "stratified random sampling" (Shafer, 2016; Vogelsang and Wendt, 2018). Systematic archaeological and geomorphological surveys of the western Bisare River and Bilate River were undertaken in 2006 by the research group around De la Torre et al. (2007) and in 2011, 2012, and 2014 by the research team of the Collaborative Research Centre 806 (CRC806) "Our way to Europe". The excavations at Sodicho Rockshelter on Mt Sodicho started in 2015.

\subsection{GIS-based analyses}

The image analysis software ENVI ( 5.3 by Harris Geospatial Solutions) was used to extract high-resolution digital elevation models (DEM) using panchromatic images of Pléiades 1A (by Astrium Services/Spot Image, Airbus Defence and Space) satellites, with a $2 \mathrm{~m}$ resolution, and ASTER GDEM data (by METI and NASA), with a resolution of $30 \mathrm{~m}$. For this, identical tie points on both satellite images were manually fitted together to create panchromatic images. The highresolution DEMs generated from the Pléiades satellite scenes cover areas spanning Mt Sodicho, Mt Damota, and the Bisare River catchment, and singular ASTER scenes were used to fill gaps.

Surface and hydrological data were determined by a Geographical Information System (ArcGIS 10.6 by ESRI) using the beforehand-created DEMs functioning as base "maps". The modelling tools of Arc Hydro (ESRI) were used for the extraction of the hydrological features, such as flow direction and accumulation, surface runoff, and catchment areas. The calculated GIS data sets can be requested from the CRC 806 Database via https://doi.org/10.5880/SFB806.49. These parameters allowed a quantitative raster- and vectorbased calculation of the actual drainage systems (Bolten et al., 2006). Freely available satellite images of the Google Earth Timelapse NASA Landsat programme from 2009 to 2017 were used to identify annual landscape transformations, i.e. swamp formation and reduction (Fig. 3). In addition, viewshed analyses from both mountaintops (Mt Damota and Mt Sodicho) were conducted with ArcGIS 10.6 (ESRI) to test the significance of the archaeological rock shelters at high evaluations and their importance for prehistoric huntergatherers. To do so, a body height of $1.60 \mathrm{~m}$ was defined.

\subsection{Radiocarbon dating}

Several percussion drilling cores were obtained from 11 drilling locations in the basin of the Bisare River swamps in 2014 and 2015. The drilling locations were placed over the entire swamp area. Drilling locations in the surrounding area were not considered, since the surroundings are dominated 


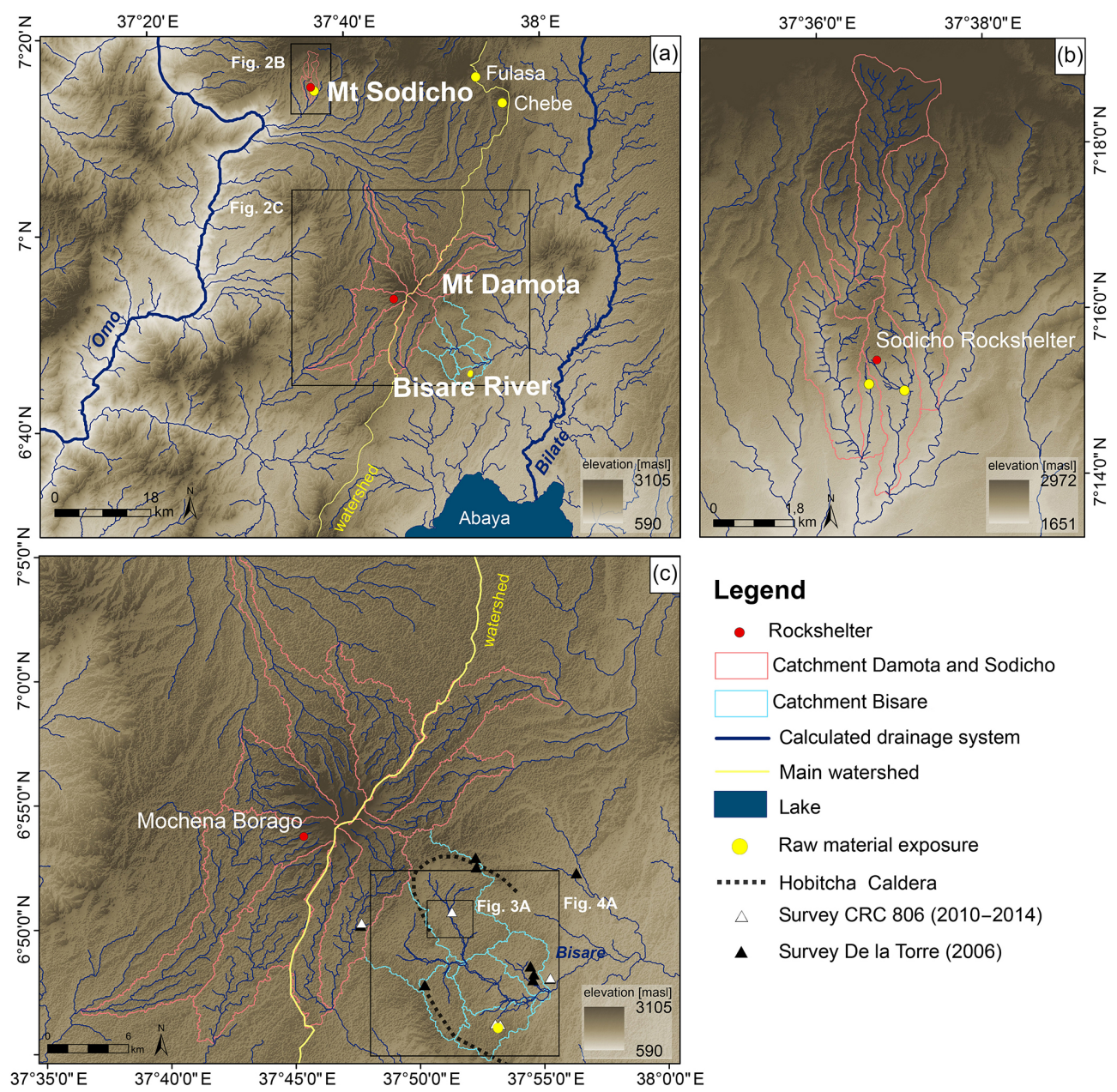

Figure 2. (a) Map showing the calculated drainage networks in the study area for the three study sites: Mt Damota, the Bisare River catchment, and Mt Sodicho. Primary drainage systems mainly support the two major south running rivers: Omo and Bilate. (b) Drainage network at the southern flank of Mt Sodicho. (c) Drainage network of Mt Damota and the Bisare River. The triangles illustrate archaeological evidence mapped by De la Torre (2006) and by the CRC 806 (2010-2014) (DEM data from Mochena and Bisare by ASTER GDEM; DEM data from Sodicho by Astrium's Pléiades; illustration by Elena Hensel).

Table 1. Radiocarbon ages for the samples from the BIS03 and BIS07 drilling cores.

\begin{tabular}{lllclrlc}
\hline Sample label & Sample ID & Material & $\begin{array}{c}\text { Depth b.s.l. } \\
(\mathrm{cm})\end{array}$ & $\begin{array}{l}\text { Age } \\
\text { (years BP) }\end{array}$ & \pm & $\begin{array}{l}\text { Age } \\
\text { (years CE) }\end{array}$ & $\begin{array}{c}\delta^{13} \mathrm{C} \\
(\%)\end{array}$ \\
\hline COL2819.1.1 & BIS03-RC1 & plant & 118 & -325 & 34 & n/a & -28.6 \\
COL3300.1.1 & BIS07-C1_W & plant & 280 & $>$ modern & - & $1957-1998$ & -11.2 \\
COL3301.1.1 & BIS07-C1_S & sediment & 280 & 25 & 35 & $1694-1919$ & -21.2 \\
\hline
\end{tabular}

n/a: not applicable.

by modern agriculture and therefore excessively influenced by human activity. In this study, we present three samples from cores BIS03 and BIS07 of the uppermost part of swamp 1 , which were tested for radiocarbon dating (Table 1). Both cores were drilled in fluvial sequences located on the edges of the swamp (Fig. 3a). The three radiocarbon samples, from either plant (BIS03-PC1 and BIS07_W) or sediment mate- rial (BIS07-C1_S), were extracted from silty to sandy sediments in the upper $3 \mathrm{~m}$ of the drilling cores. The radiocarbon AMS lab of the University of Cologne analysed the samples with acid and alkali (AAA) pre-treatment to remove inorganic carbon and humid acids. The conventional radiocarbon ages were calibrated with OxCal v. 4.2.3, applying the cal- 
ibration curve IntCal13 (Ramsey et al., 2013; Reimer et al., 2013).

\section{Results}

\subsection{GIS-based analyses}

The geomorphological and hydrological analyses of the two mountains and the Bisare River catchments were based on high-resolution DEMs that were calculated based on remote sensing data. With the help of the catchment analysis, recent large-scale drainage lines of the study area around $\mathrm{Mt}$ Damota and Mt Sodicho were defined (Fig. 2a). In combination with a geomorphological field survey, small-scale and large-scale gully erosion could be identified.

1. Mt Damota has a typical radial drainage system, which is crossed by a main watershed (Fig. 2c). This watershed is running north-south through the entire study area, separating the runoff into a western and an eastern direction. The western streams drain into the Omo River basin, whereas the eastern streams drain towards Lake Abaya but without an inflow into the Bisare River catchment. This is caused by the horseshoe-shaped Hobitcha Caldera that functions as a barrier between the eastern streams and the Bisare River catchment.

2. Mt Sodicho's stream network and drainage lines mainly flow into the Omo River basin. According to the hydrological analyses and the field observations from 2017, Mt Sodicho has a radial drainage network, which gave the mountain its characteristic irregular form (Fig. 2b). Permanent streams and seasonal creeks (only flowing during the rainy season) flow down the mountain flanks into a larger south-running dendritic drainage network that belongs to the drainage network of the Wagebeta Caldera Complex. Nowadays, the surface morphology on Mt Sodicho is influenced by intensive agriculture. Small-scale surface erosion $(10-20 \mathrm{~m}$ in width) was mapped on the upper slopes (Fig. 1c). In the past, the vegetation was probably removed to create cultivation areas, which are now jeopardized by increasing erosion. These active gullies are currently used as pathways for the local population and their cattle, which further enhances degradation and runoff. Raw material provenance of lithic artefacts that were found at Mt Sodicho is still not proven. So far, obsidian raw material with distinct signs of transport could be observed as fluvially transported boulders or debris along the surrounding drainage systems and river banks. In Fig. 2b, these raw material findings are illustrated as yellow dots. Additionally, two obsidian outcrops were discovered to the east of Mt Sodicho during the latest survey in November 2018. Within a distance of 30-36 km from Sodicho Rockshelter, the two outcrops named Chebe and Fulasa were still in the range of movement of the Late Pleistocene hunter-gatherers (Fig. 2a).

3. The Bisare River flows into the Bilate River. The latter is the main tributary of the $15000 \mathrm{~km}^{2}$ large catchment of Lake Abaya (Chernet, 2011). Based on the hydrological and geomorphological analyses, different geomorphic features could be observed (Fig. 2c): the research area lies within a dynamic hydrological system, showing a high to moderate runoff of surface water (Berhaun et al., 2013). With the help of a longitudinal profile, starting at the Bisare River catchment and following the Bilate River into Lake Abaya, a sudden change in the slope (knickpoint) could be identified. This knickpoint is situated $\sim 15 \mathrm{~km}$ along the profile, where the river flows out from the Hobitcha Caldera (Fig. 5). The study of knickpoints can be used to identify potential areas for sedimentation. Three connected swamps of different sizes and altitudes formed in low-energy parts of the river valley in the upper part of the catchment (Fig. 3). They were documented during geomorphological field mapping in 2014. A highly exaggerated longitudinal profile, running transversely through the lakes, illustrates the local stair-like morphology. Unlike swamp 3, the two upper basins of swamps 1 and 2 are situated in an area with highly dynamic permanent and episodic streams. Via satellite imagery (Google Earth Timelapse NASA Landsat programme), we observed that the two upper swamps are supplied by episodic tributaries during wet seasons (Fig. 3b-d). Gully erosion and sheetwash erosion are widespread phenomena particularly in the lower part of the Bisare catchment (Fig. 4a). Here, surface runoff and erosion-outcropped artefact assemblages are predominantly from the Middle Stone Age (De La Torre et al., 2007). These assemblages were preserved in Pleistocene alluvial soils at the flanks of the river basin. Also, outcrops of in situ obsidian raw material and scattered lithic surface finds were found by De La Torre et al. (2007) and our research team in the southern degraded areas. Formerly buried material was exposed to the surface, and the lithics had been partly transported due to constant erosion and extensive badlands formation, mainly at the lower part of the river catchment. Erosion and badlands formation initiated from the edge of the rift valley and spread upstream of the Bisare (Fig. 4c-e). Figure 4d and e visualize subsurface material cropping out in this degraded area, which varies between reddish-brown regolith and greyish ignimbrite.

According to the viewshed analyses from the mountaintops of Mt Damota and Mt Sodicho, all-round views over the landscape are possible. The views reach from the lakes of the central Main Ethiopian Rift Valley in the distant north, over the Bilate River in the east, Lake Abaya to the south, the Gibe and Omo river valleys to the southwest, and up the Wolayta- 


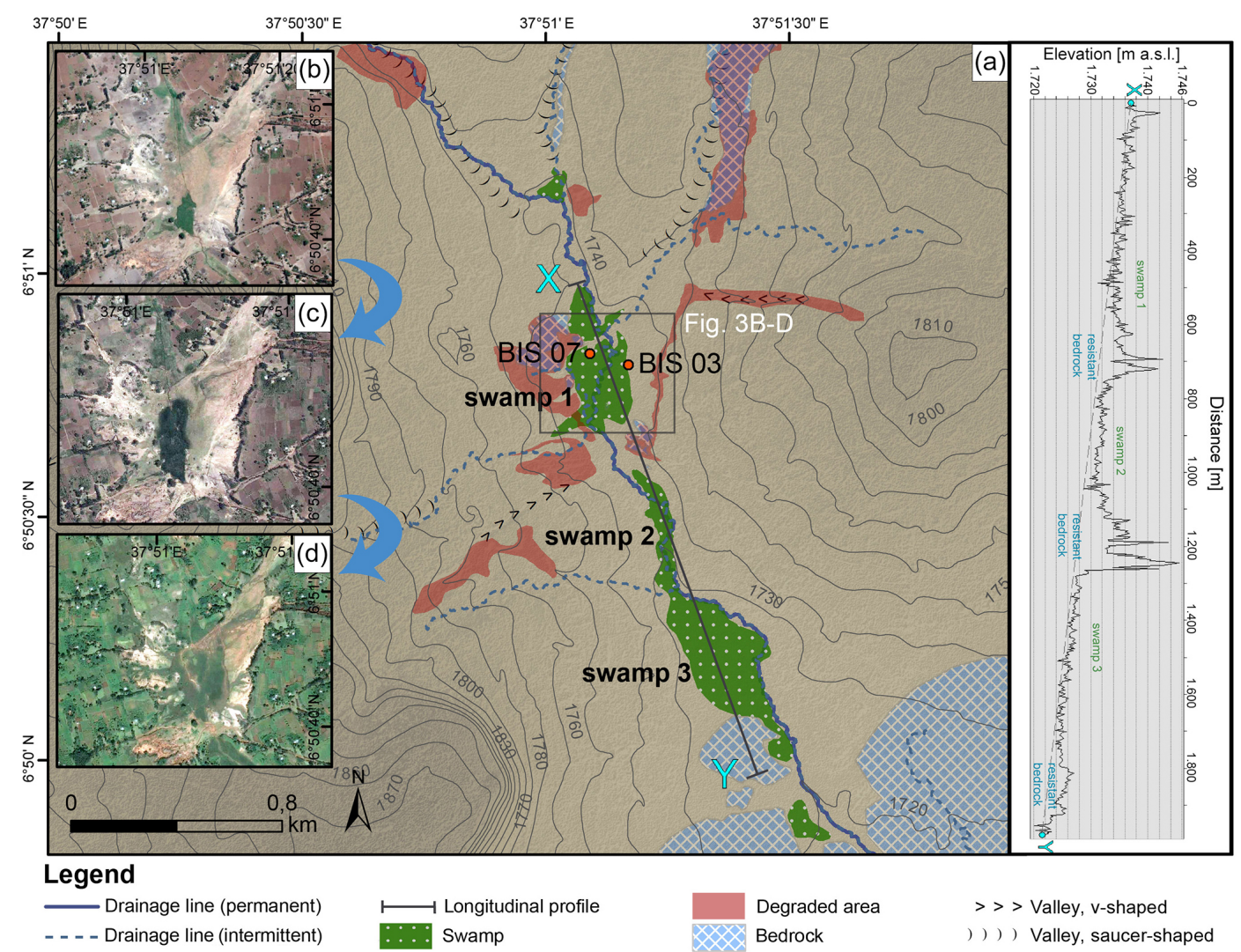

Figure 3. (a) Map showing the dimension of the three swamps on the Bisare River. The positions of the two drillings in swamp 1 are marked with red dots (DEM data by ASTER GDEM). The sequence of images (b)-(d) illustrates the changes of swamp 1 during different wet and dry phases: (b) following a dry season (21 March 2009), (c) following a wet season (15 November 2009), and (d) during a wet season (17 October 2014) (swamp data set by Svenja Meyer; Satellite images by @Google Earth Timelapse NASA Landsat programme). The super-elevated longitudinal profile X-Y illustrates the geomorphological position of the swamps in the Bisare River basin, leading to a step-like topography, extracted from the DEM based on Pléiades 1A satellite imagery (DEM data by ASTER GDEM; illustration by Elena Hensel).

Hadiya Highlands to the west. During clear weather conditions, the opening area of the Sodicho Rockshelter offers a complete view to Mt Damota and the Omo River basin in the west (Fig. 1c). The view directly from Mochena Borago is limited to the southeast and east, and therefore Mt Sodicho is out of sight. These results verify a locational advantage of both rock shelters, i.e. Mochena Borago on Mt Damota and Sodicho Rockshelter on Mt Sodicho, for watching game in the surrounding lowlands.

\subsection{Radiocarbon dating}

The modern radiocarbon ages of two botanical samples (BIS03-PC1 and BIS07_W) and one sediment sample (BIS07-C1_S), originating from two drilling cores taken in a depth of up to $2 \mathrm{~m}$ below the surface level in the uppermost part of swamp 1, revealed that the upper $3 \mathrm{~m}$ of the sedimentary basin fill are of modern age (Table 1). This demonstrates a high sedimentation rate at least in this swamp.

\section{Discussion}

Several processes of degradation, such as gully or river erosion, led to the exposure of obsidian raw material localities and open-air sites with scatters of stone artefacts (Fig. 4ad). This is particularly true in the Bisare River basin with its areas of different stream energy where the swamps form sediment traps for the eroded material today. One main question was why these step-like swamps formed and if their formation process can be used to obtain paleoenvironmental information. We propose that during wetter phases stronger gully erosion is activated, and resulting sediment slugs are able to hold up further sediment flux. This can be described as a cutand-fill process with sediment accumulation in times with relatively intensive erosion and active gullying, and channel incision in periods of less active gullying, e.g. less intensive erosion (Nanson and Croke, 1992; Brierley and Fryirs, 1999; Fryirs and Brierley, 2013; Orti et al., 2019). The consequence is swamp development due to damming of the stream and sediment trapping. Therefore, this area can be assumed to 


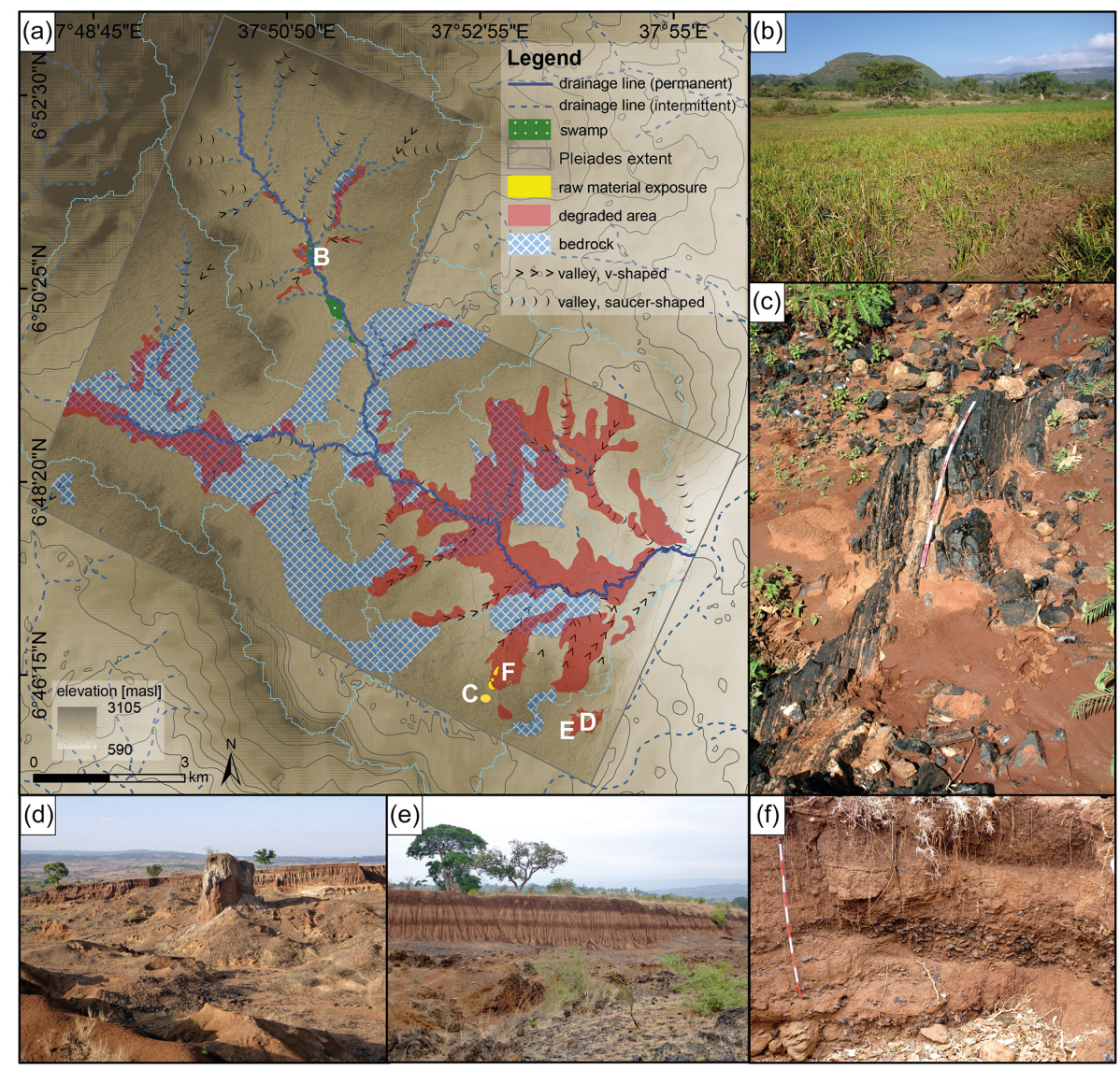

Figure 4. (a) Map showing the Bisare River catchment. Degraded areas are mainly characterized by gully erosion. (b) Image of the wet, swampy area in the upper part of the catchment (swamp 1). (c) Obsidian raw material outcrop. (d) Badlands formation and gully erosion is a common phenomenon in the depressions of the catchment. (e) Gully-erosion-exposed paleosols alternating with volcanic ash. (f) Relocated obsidian flakes exposed in a gully of a degraded area (swamp data set by Svenja Meyer; photography by Olaf Bubenzer; illustration by Elena Hensel).

be very sensitive towards external changes and disturbances, e.g. a change in sediment flux rate. The southernmost part of swamp 3 has the widest dimension, which is most probably the result of a change of bedrock (Fig. 3). A more resistant rock type must have created a natural "bottleneck", which caused natural damming that was intensified by additional damming by sediment slugs during certain periods. As a consequence, the slow-moving water got dammed up, leading to sedimentation and preventing erosion of these accumulated sediments (Machado, 2015). Generally, changes of sediment supply from tributaries into the Bisare and then into the Bilate River must have had a significant geomorphological effect on the main hydrological system in the form of the incision and subsequent aggradation of transported material. In summary, we view this as a geogenic sediment cascade system, where relatively young sediments should have been transported into the lower basin only after the higher basins were filled up (Fig. 3a) (Fryirs and Brierley, 2013; Fryirs, 2016). However, the radiocarbon samples (BIS07-C1) of the sediment in the uppermost basin yielded modern ages, al- though they are assumed to contain the oldest sediments (Table 1). With a possible sediment cascade and our radiocarbon dates in mind, we state that the development of the swamps must be a relatively recent phenomenon that is linked with the current high erosion and accumulation rates in the area of the Bisare River. Therefore, we suggest that the surficial Pleistocene deposits that are currently largely being exposed by badlands formation in the region must have been completely removed by fluvial erosion, leading to formation of the basins. Afterwards, the basins were refilled by the recent fine-grained sediment that we dated with radiocarbon (Table 1).

With respect to the present-day lithic raw material accessibility and preservation, our geomorphological field observations from 2014 and 2015 coincide with the published observations by Vogelsang and Wendt (2018) on obsidian outcrops in the Humbo area of the Bisare River catchment (Fig. 2c). These authors state that the predominance of obsidian for the production of stone artefacts is not surprising, considering the proximity of the rich sources in the Humbo area to known 
archaeological sites (Vogelsang and Wendt, 2018). Furthermore, the glassy structure of the obsidian allows a very precise production of lithic tools (Rapp, 2009). Together, this could explain the extreme dominance of obsidian in all lithic assemblages. However, the question arises whether the activity of the hydrological system and erosion processes at Bisare had a comparable intensity during Late Pleistocene and early Holocene to mid-Holocene, leading to the exposure of a similar amount of raw material. If this was not the case, hunter-gatherers were not able to focus only on the local obsidian deposit in the Humbo area but had to select alternative sources. In this context, also the effects of today's vegetation have to be considered. Today's intensive farming and deforestation, e.g. at the flanks of Mt Sodicho, strongly changed the actual surface runoff but might also directly destroy archaeological deposits. The current destruction and relocation of raw material is visible in the form of scattered obsidian debris and large boulders found along the streams at Mt Sodicho (Fig. 2b). At the moment, we cannot verify if prehistoric hunter-gatherers were able to use such kinds of displaced raw material, but this would be an interesting question for future research. Generally, we think that understanding the hydrological system is fundamental for the evaluation of obsidian raw material availability in this area. However, we still do not know the rate and the start of gully erosion and badlands formation in our study area that are known as inhomogeneous processes - in intensity as well as in duration (Castillo and Gómez, 2016). If the Late Pleistocene hydrological system was as highly dynamic as it is today, gully erosion might have already been initiated by natural processes during that period. We only expect this for certain climatic phases in which the paleoenvironmental conditions promoted such a dynamic system due to higher precipitation. Accordingly, several studies demonstrated variable climatic conditions at the Horn of Africa during the Late Pleistocene and Holocene. Transitions from humid to arid conditions and vice versa led to rise and shrinkage of lake levels and also affected the connecting drainage networks (Sagri et al., 2008; Carnicelli et al., 2009; Foerster et al., 2012; Junginger and Trauth, 2013; Foerster et al., 2015; Trauth et al., 2019). We propose that the connected drainage systems in our research area, such as the Bisare River, might have reacted to these transitions with changes in their depositional and erosional behaviour. Furthermore, considering the location of our research areas within a region that have been tectonically active since the Plio-Pleistocene, we can assume that the aforementioned extensive surface processes most likely started already during the Late Pleistocene (Fig. 5). However, we propose that due to today's intensified human impact in the form of clearance of the vegetation cover and cropland expansion, leading to higher runoff, obsidian raw material comes more frequently and in higher amounts up to the surface than during prehistoric times.

Archaeological evidence from Mt Damota and Sodicho Rockshelter shows that groups of prehistoric humans seem

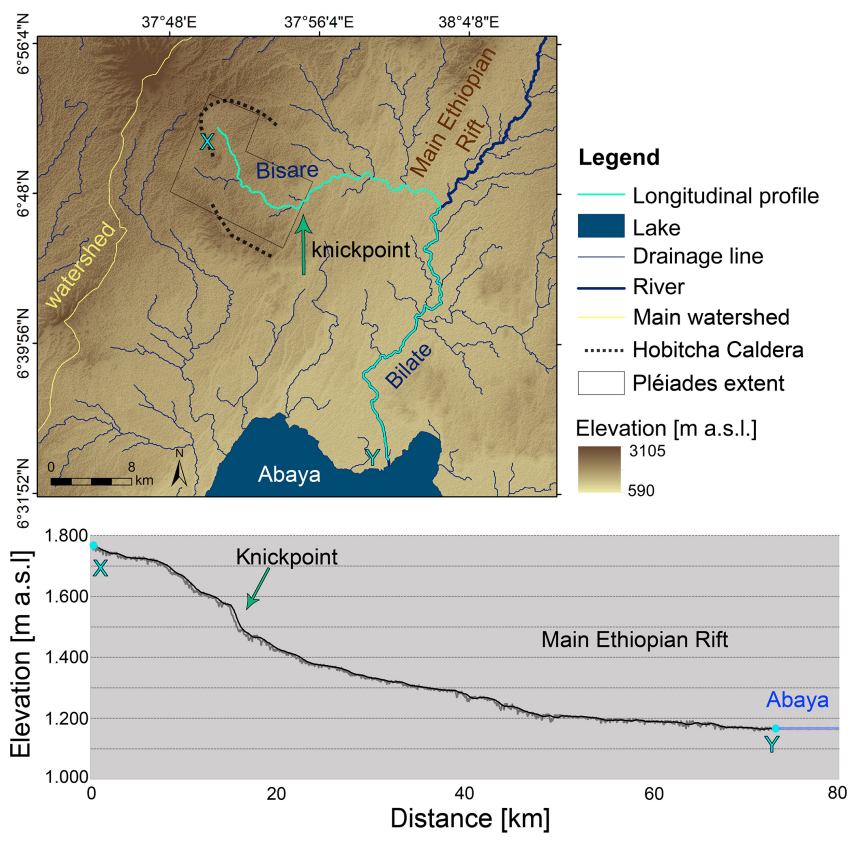

Figure 5. Map showing the calculated drainage networks southeast of the Bisare River catchment that flow into Lake Abaya. Following the longitudinal profile of the Bisare River (green line and graph), a sudden change in slope (knickpoint) at the outflow from the Hobitcha Caldera stands out (DEM data by ASTER GDEM; illustration by Elena Hensel).

to have adapted to former climatic and hydrological changes, leading to different environmental conditions, with repeated occupation of the rock shelters at higher elevations under different environmental conditions (Brandt et al., 2012, 2017; Vogelsang and Wendt, 2018). During such periods these groups were probably exploiting these higher elevated areas with the awareness of their sufficient water and food resources, shelter, and the access to obsidian raw material (cf. Vogelsang et al., 2018). Although it is not yet clear which specific obsidian outcrops were used by the prehistoric humans, first results of obsidian microprobe analysis point to the exploitation of raw material from outcrops in the Bisare area by the inhabitants of both rock shelters (Vogelsang, unpublished information, 2019).

\section{Conclusions}

This study gives an insight into to the potential of a combination of hydrological and geomorphological analyses by applying field surveys, remote sensing, geographical information systems, and radiocarbon dating, as well as investigations of the archaeological site distribution, to reconstruct the interplay between past hydrological conditions and Paleolithic settlement activity in a mountainous area of the southwestern Ethiopian Highlands. With our results, we were able to describe the current landscape dynamics and the actual 
state of known rock shelters and open-air sites, as well as raw material preservation in the study areas. The preserved evidence for repeated human occupation during the Late Pleistocene and Holocene at Sodicho Rockshelter (Vogelsang, unpublished information, 2015 to 2018) hints that the highlands could have provided a refugium during arid phases such as the Last Glacial Maximum (LGM, $\sim 21 \pm 2 \mathrm{ka}$ ) (Mark and Osmaton, 2008). At Mochena Borago, settlement activities reach back $>50 \mathrm{ka}$. During such periods, the exploitation of different, elevation-bound ecosystems allowed access to a heterogeneous spectrum of faunal and lithic resources for prehistoric humans (Vogelsang and Wendt, 2018). Humidarid transitions in the past must have led to pronounced erosion and badlands formation. We suggest that there is a relationship between widespread gully erosion, badlands formation, and raw material availability. Currently, the study area is a region with strong recent sediment erosion and simultaneous accumulation in a cascading system. Looking into the future, given strongly increased human impact during the last few decades acting together with the currently very active hydrological system, intensified soil loss will lead to further degradation of the archaeological material. However, the transfer of today's circumstances into prehistoric times is complicated, as we cannot prove that currently active processes, e.g. swamp formation, were also active during the Pleistocene. Furthermore, the research sites are situated in an area close to the Main Ethiopian Rift, i.e. a region with pronounced tectonic activity that also has a significant impact on the regional geomorphodynamics. Therefore, at this stage the results do not allow any distinct statement about the transfer of the modern morphodynamics to ancient times, as we have identified only recent phenomena. This means that the calculated drainage lines show the current state in a very active hydrological system that is influenced by both natural effects and intensive human activity. Nevertheless, in the context of further interdisciplinary research that combines wellresolved archaeological and alluvial chronostratigraphies it will be possible to obtain a better general understanding of the interplay between former settlement activity and paleoenvironmental conditions in the Ethiopian Highlands during the Pleistocene.

Data availability. GIS data sets can be requested from the CRC 806 Database via https://doi.org/10.5880/SFB806.49 (Hensel et al., 2019).

Author contributions. The geomorphological field mapping and drilling were carried out by $\mathrm{OBu}$ and $\mathrm{OB}$. Archaeological survey was conducted by RV. EAH performed GIS-based mapping, geomorphological-hydrological analyses, and preparation of the paper. All co-authors contributed to, read, and approved the paper.
Competing interests. The authors declare that they have no conflict of interest.

Special issue statement. This article is part of the special issue "Geoarchaeology and past human-environment interactions". It is not associated with a conference.

Acknowledgements. We kindly thank the Authority for Research and Conservation of Cultural Heritage (ARCCH) of Ethiopia for their permission and general support, and the Ministry of Mines and Energy for the approval of our export permits. This study was conducted as a part of project A1 "Out of Africa - Late Pleistocene Rock Shelter Stratigraphies and Palaeoenvironments in Northeast Africa" in the framework of the Collaborative Research Centre 806 (CRC 806) "Our way to Europe”. We thank Janet Rethemeyer and colleagues from the radiocarbon AMS lab of the University of Cologne for radiocarbon dating the Bisare samples. We are very grateful to Svenja Meyer for her great effort for project A1 and for her participation during various field seasons in Ethiopia especially. Special thanks also go to Taylor Otto for the English proofreading, as well as to Minassie Tekelemariam and Bahru Zinaye for their support in the field. We thank Andrea Zerboni, an anonymous referee, and the editors for constructive and insightful comments, which significantly helped to improve this paper.

Financial support. This research has been supported by the Deutsche Forschungsgemeinschaft (DFG, German Research Foundation) (grant no. 57444011 - SFB 806).

\section{References}

Abbate, E., Bruni, P., and Sagri, M.: Geology of Ethiopia: a review and geomorphological perspectives, in: Landscapes and Landforms of Ethiopia, edited by: Billi, P., Springer, Dordrecht, the Netherlands, 33-64, https://doi.org/10.1007/978-94-017-80261_2, 2015.

Basell, L. S.: Middle Stone Age (MSA) site distributions in eastern Africa and their relationship to Quaternary environmental change, refugia and the evolution of Homo sapiens, Quaternary Sci. Rev., 27, 2484-2498, https://doi.org/10.1016/j.quascirev.2008.09.010, 2008.

Benito-Calvo, A., De la Torre, I., Mora, R., Tibebu, D., Morán, N., and Martínez-Moreno, J.: Geoarchaeological potential of the western bank of the Bilate River (Ethiopia), Analele Universităţii din Oradea, Seria Geographie, XVII, 99-104, 2007.

Berhanu, B., Melesse, A. M., and Seleshi, Y.: GIS-based hydrological zones and soil geo-database of Ethiopia, CATENA, 104, 21-31, https://doi.org/10.1016/j.catena.2012.12.007, 2013.

Billi, P. and Dramis, F.: Geomorphological investigations on gully erosion in the Rift Valley and the northern highlands of Ethiopia, CATENA, 50, 353-368, https://doi.org/10.1016/S03418162(02)00131-5, 2003.

Bolten, A., Bubenzer, O., and Darius, F.: A digital elevation model as a base for the reconstruction of Holocene land- 
use potential in arid regions, Geoarchaeology, 21, 751-762, https://doi.org/10.1002/gea.20137, 2006.

Bonini, M., Corti, G., Innocenti, F., Manetti, P., Mazzarini, F., Abebe, T., and Pecskay, Z.: Evolution of the Main Ethiopian Rift in the frame of Afar and Kenya rifts propagation, Tectonics, 24, 1-21, https://doi.org/10.1029/2004TC001680, 2005.

Brandt, S., Hildebrand, E., Vogelsang, R., Wolfhagen, J., and Wang, H.: A new MIS 3 radiocarbon chronology for Mochena Borago Rockshelter, SW Ethiopia: Implications for the interpretation of Late Pleistocene chronostratigraphy and human behavior, J. Archaeol. Sci. Reports, 11, 352-369, https://doi.org/10.1016/j.jasrep.2016.09.013, 2017.

Brandt, S. A., Fisher, E. C., Hildebrand, E. A., Vogelsang, R., Ambrose, S. H., Lesur, J., and Wang, H.: Early MIS 3 occupation of Mochena Borago Rockshelter, Southwest Ethiopian Highlands: implications for Late Pleistocene archaeology, paleoenvironments and modern human dispersals, Quatern. Int., 274, 38 54, https://doi.org/10.1016/j.quaint.2012.03.047, 2012.

Brierley, G. J. and Fryirs, K.: Tributary-trunk stream relations in a cut-and-fill landscape: a case study from Wolumla catchment, New South Wales, Australia, Geomorphology, 28, 61-73, https://doi.org/10.1016/S0169-555X(98)00103-2, 1999.

Carnicelli, S., Benvenuti, M., Ferrari, G., and Sagri, M.: Dynamics and driving factors of late Holocene gullying in the Main Ethiopian Rift (MER), Geomorphology, 103, 541-554, https://doi.org/10.1016/j.geomorph.2008.07.019, 2009.

Castillo, C. and Gómez, J. A.: A century of gully erosion research: Urgency, complexity and study approaches, Earth Sci. Rev. 160, 300-319, https://doi.org/10.1016/j.earscirev.2016.07.009, 2016.

Chernet, T.: Geology and hydrothermal resources in the northern Lake Abaya area (Ethiopia), J. Afr. Earth. Sci., 61, 129-141, https://doi.org/10.1016/j.jafrearsci.2011.05.006, 2011.

Corti, G.: Continental rift evolution: from rift initiation to incipient break-up in the Main Ethiopian Rift, East Africa, Earth. Sci. Rev., 96, 1-53, https://doi.org/10.1016/j.earscirev.2009.06.005, 2009.

Corti, G., Sani, F., Philippon, M., Sokoutis, D., Willingshofer, E., and Molin, P.: Quaternary volcano-tectonic activity in the Soddo region, western margin of the Southern Main Ethiopian Rift, Tectonics, 32, 861-879, https://doi.org/10.1002/tect.20052, 2013.

De La Torre, I., Benito-Calvo, A., Mora, R., Martínez-Moreno, J., Morán, N., and Tibebu, D.: Stone Age occurrences in the western bank of the Bilate River (Southern Ethiopia) - Some preliminary results, Nyame Akuma, 67, 14-25, 2007.

Foerster, V., Junginger, A., Langkamp, O., Gebru, T., Asrat, A., Umer, M., Lamb, H.F., Wennrich, V., Rethemeyer, J., Nowaczyk, N., Trauth, M. H., and Schaebitz, F.: Climatic change recorded in the sediments of the Chew Bahir basin, southern Ethiopia, during the last 45,000 years, Quaternary Int., 274, 25-37, https://doi.org/10.1016/j.quaint.2012.06.028, 2012.

Foerster, V., Vogelsang, R., Junginger, A., Asrat, A., Lamb, H. F., Schaebitz, F., and Trauth, M. H.: Environmental change and human occupation of southern Ethiopia and northern Kenya during the last 20,000 years, Quaternary Sci. Rev., 129, 333-340, https://doi.org/10.1016/j.quascirev.2015.10.026, 2015.

Friis, I., Sebsebe, D., and Breugel, P.: Atlas of the potential vegetation of Ethiopia, Det Kongelige Danske Videnskabernes Selskab, Copenhagen, 2010.
Fryirs, K. A.: River sensitivity: a lost foundation concept in fluvial geomorphology, Earth Surf. Proc. Land., 42, 55-70, https://doi.org/10.1002/esp.3940, 2016.

Fryirs, K. A. and Brierley, G. J.: Geomorphic analysis of river systems: an approach to reading the landscape, John Wiley \& Sons, Chichester, West Sussex, England, 2013.

Griffiths, J.: Ethiopian highlands, World survey of climatology, 10, 369-381, 1972.

Hensel, E. A., Bödeker, O., Bubenzer, O., and Vogelsang, R.: Combining geomorphological-hydrological analyses and the location of settlement and raw material sites - a case study on understanding prehistoric human settlement activity in the southwestern Ethiopian Highlands, E\&G Quaternary Sci. J., 69, 1-14, https://doi.org/10.5194/egqsj-69-1-2019, 2019.

Junginger, A. and Trauth, M. H.: Hydrological constraints of paleoLake Suguta in the Northern Kenya Rift during the African humid period (15-5 ka BP), Global Planet. Change, 111, 174-188, https://doi.org/10.1016/j.gloplacha.2013.09.005, 2013.

Junginger, A., Vonhof, H., and Foerster, V. E.: AGU Fall Meeting Abstracts, How wet is wet? Strontium isotopes as paleo-lake level indicators in the Chew Bahir basin (S-Ethiopia), American Geophysical Union, Fall Meeting 2016, (abstract no. PP23A2310), 2016.

Machado, M. J.: Geomorphology of the Adwa District, in: Landscapes and Landforms of Ethiopia, edited by: Billi, P., Springer, Dordrecht, Netherlands, 163-178, https://doi.org/10.1007/97894-017-8026-1, 2015.

Mark, B. G. and Osmaton, H. A.: Quaternary glaciation in Africa: Key chronologies and climatic implications, J. Quaternary Sci., 23, 589-608, https://doi.org/10.1002/jqs.1222, 2008.

Mukai, S.: Gully erosion rates and the analysis of determining factors: A case study from the semi-arid Main Ethiopian Rift Valley, Land Degrad. Dev., 28, 607-615, https://doi.org/10.1002/ldr.2532, 2017.

Nanson, G. C. and Croke, J. C.: A genetic classification of floodplains, Geomorphology, 4, 459-486, https://doi.org/10.1016/0169-555X(92)90039-Q, 1992.

Nicholson, S. E.: The ITCZ and the seasonal cycle over equatorial Africa, B. Am. Meteorol. Soc., 99, 337-348, https://doi.org/10.1175/BAMS-D-16-0287.1, 2018.

Orti, M. V., Negussie, K., Corral-Pazos-De-Provens, E., Höfle, B., and Bubenzer, O.: Comparison of Three Algorithms for the Evaluation of TanDEM-X Data for Gully Detection in Krumhuk Farm (Namibia), Remote Sensing, 11, 1327, https://doi.org/10.3390/rs11111327, 2019.

Ramsey, C., Scott, E., and Van der Plicht, J.: Calibration for Archaeological and Environmental Terrestrial Samples in the Time Range 26-50 ka cal BP, Radiocarbon, 55, 2021-2027, https://doi.org/10.2458/azu_js_rc.55.16935, 2013.

Rapp, G.: Lithic Materials, in: Archaeomineralogy, Natural Science in Archaeology, edited by: Rapp, G., Springer, Berlin, Heidelberg, Germany, 60-90, https://doi.org/10.1007/978-3-54078594-1_4, 2009.

Reimer, P. J., Bard, E., Bayliss, A., Beck, J. W., Blackwell, P. G., Ramsey, C. B., Buck, C. E., Cheng, H., Edwards, R. L., Friedrich, M., Grootes, P. M., Guilderson, T. P., Haflidason, H., Hajdas, I., Hatté, C., Heaton, T. J., Hoffmann, D. L., Hogg, A. G., Hughen, K. A., Kaiser, K. F., Kromer, B., Manning, S. W., Niu, M., Reimer, R. W., Richards, D. A., Scott, E. M., 
Southon, J. R., Staff, R. A., Turney, C. S. M., and van der Plicht, J.: IntCal13 and Marine13 Radiocarbon Age Calibration Curves 0-50,000 Years cal BP, Radiocarbon, 55, 1869-1887, https://doi.org/10.2458/azu_js_rc.55.16947, 2013.

Sagri, M., Bartolini, C., Billi, P., Ferrari, G., Benvenuti, M., Carnicelli, S., and Barbano, F.: Latest Pleistocene and Holocene river network evolution in the Ethiopian Lakes Region, Geomorphology, 94, 79-97, https://doi.org/10.1016/j.geomorph.2007.05.010, 2008.

Schütt, B.: Deposition of modern fluvio-lacustrine sediments in Lake Abaya, South Ethiopia - A case study from the delta areas of Bilate River and Gidabo River, northern basin, Z. Geomorph. N. F., 138, 131-151, 2005.

Segele, Z. T., Lamb, P. J., and Leslie, L. M.: Large-scale atmospheric circulation and global sea surface temperature associations with Horn of Africa June-September rainfall, Int. J. Climatol., 29, 1075-1100, https://doi.org/10.1002/joc.1751, 2009.

Shafer, H. J.: Research design and sampling techniques, in: Field Methods in Archaeology, edited by: Hester, T. R., Shafer, H. J., and Feder, K. I., Routledge, Oxford, England, 2016.

Tierney, J. E., Russell, J. M., Huang, Y., Damsté, J. S. S., Hopmans, E. C., and Cohen, A. S.: Northern Hemisphere Controls on Tropical Southeast African Climate During the Past 60,000 Years, Science, 322, 252-255, https://doi.org/10.1126/science.1160485, 2008.

Tierney, J. E., Lewis, S. C., Cook, B. I., LeGrande, A. N., and Schmidt, G., A.: Model, proxy and isotopic perspectives on the East African Humid Period, Earth Planet. Sc. Lett., 307, 103112, https://doi.org/10.1016/j.eps1.2011.04.038, 2011.
Trauth, M. H., Asrat, A., Duesing, W., Foerster, V., Kraemer, K. H., Marwan, N., Maslin, M. A., and Schaebitz, F.: Classifying past climate change in the Chew Bahir basin, southern Ethiopia, using recurrence quantification analysis, Clim. Dynam., 53, 116, https://doi.org/10.1007/s00382-019-04641-3, 2019.

Viste, E. and Sorteberg A.: Moisture transport into the Ethiopian highlands, Int. J. Climatol., 33, 249-263, https://doi.org/10.1002/joc.3409, 2013.

Vogelsang, R. and Wendt, K. P.: Reconstructing prehistoric settlement models and land use patterns on Mt. Damota/SW Ethiopia, Quatern. Int., 485, 140-149, https://doi.org/10.1016/j.quaint.2017.06.061, 2018.

Vogelsang, R., Bubenzer, O., Kehl, M., Meyer, S., Richter, J., and Zinaye, B.: When Hominins Conquered Highlands - an Acheulean Site at $3000 \mathrm{~m}$ a.s.l. on Mount Dendi/Ethiopia, Journal of Paleolithic Archaeology, 1, 302-3013, https://doi.org/10.1007/s41982-018-0015-9, 2018.

Woldegabriel, G., James, L. A., and Robert, C. W.: Geology, geochronology, and rift basin development in the central sector of the Main Ethiopian Rift, Geol. Soc. Am. B., 102, 439-485, https://doi.org/10.1130/00167606(1990)102<0439:GGARBD>2.3.CO;2, 1990. 